\title{
Reproductive biology and diet composition of Rhynchobatus laevis (Bloch and Schneider, 1801) (Rhinopristiformes:Rhinidae) from the northern Indian Ocean
}

\author{
G. B. PURUSHOTTAMA, S. G. RAJE, THAKURDAS, K. V. AKHILESH, SHOBA JOE \\ KIZHAKUDAN AND P. U. ZACHARIA \\ ICAR-Central Marine Fisheries Research Institute, P. O. Box 1603, Ernakulam North, P. O., Kochi - 682018 \\ Kerala, India \\ e-mail: puru44@gmail.com
}

\begin{abstract}
Large sized batoids particularly wedgefishes are highly vulnerable to fishing and yet very few studies have been published on their biology. The reproductive biology and feeding habit of Rhynchobatus laevis (Bloch and Schneider, 1801) collected off the north-west coast of India, Arabian Sea, northern Indian Ocean is presented. A total of 328 individuals, in the size range from 44.0 to $290 \mathrm{~cm}$ total length (TL), 300 to $94000 \mathrm{~g}$ total weight (TW) were used for the study. The length-weight relationships were significantly different between the sexes $(\mathrm{p}<0.001)$. Co-efficients ' $a$ ' and ' $b$ ' of the length-weight relationship were estimated as 0.009412 and $2.830218\left(\mathrm{r}^{2}=0.979\right)$ for females and 0.004032 and $3.031303\left(\mathrm{r}^{2}=0.974\right)$ for males, respectively. The length at maturity $\left(\mathrm{L}_{\mathrm{m}}\right)$ for females and males was estimated to be 190 and $140 \mathrm{~cm}$ TL, respectively. Number of embryos ranged from 4 to 10 and the size at birth was estimated to range between 44 and $50 \mathrm{~cm}$ TL. Overall sex ratio favoured females (Female:Male $=1.73: 1$ ). There was no significant correlation between maternal TL and number of embryos produced. Dietary analysis of stomach contents (\%IRI) revealed that $R$. laevis fed primarily on teleosts $(83.4 \%)$ and crustaceans (15.1\%). This study provides the detailed biological observation on size, sex composition, length at maturity $\left(\mathrm{L}_{\mathrm{m}}\right)$, length-weight relationship and diet of $R$. laevis from northern Indian Ocean which can be used as essential inputs to formulate effective management plans and conservation strategies for this species in the region.
\end{abstract}

Keywords: Elasmobranchs, Embryo, Guitarfish, Length at maturity, Length-weight relationship

\section{Introduction}

The distribution, biology and status of guitarfishes are poorly known in the Indian Ocean and especially from India, even though they are of high conservation concern. Guitarfishes (Family Rhinidae) comprise at least 10 species and 3 genera and of these, the genus Rhynchobatus includes the large guitarfishes. Rhynchobatus genus is present from warm temperate to tropical waters (Last et al., 2016b) with their taxonomy and biogeography being poorly defined in the Indian Ocean. In fact, the giant guitarfish Rhynchobatus djiddensis is now believed to be a complex of several species including the broadnose wedgefish Rhynchobatus springeri Compagno and Last, 2010; white-spotted guitarfish or white-spotted wedgefish Rhynchobatus australiae Whitley, 1939; the smoothnose wedgefish Rhynchobatus laevis (Bloch and Schneider, 1801); R. cf. djiddensis 1; R. cf. djiddensis 2 and Rhynchobatus cooki Last, Kyne and Compagno, 2016 (Bineesh et al., 2014; Henderson et al., 2016; Last et al., 2016a,b; Jabado, 2018; Purushottama et al., 2018).
The Rhynchobatus spp. in northern Arabian Sea of Indian exclusive economic zone (EEZ) was historically called as "Rhynchobatus djiddensis" and is considered to be widely distributed along the entire Indian coastal waters (Talwar and Kacker, 1984; Raje et al., 2007). Considering that the taxonomic status of Rhynchobatus species is not verified and as the specimen studied here does not match well with $R$. djiddensis mentioned in Last et al. (2016b), with several differences in colouration, morphometry and genetics, we refer to the species investigated in the present study as Rhynchobatus laevis and those reported by Raje et al. (2007) from the same region also as $R$. laevis. $R$. laevis is not directly targeted but caught as bycatch in trawl, gillnet and bottom-set gillnet fisheries in India. However, some information on the landings of Rhynchobatus spp. ['whitespotted wedgefish' (i.e. $R$. djiddensis) species complex] from northern Arabian Sea coast of India is available. Raje (2006) reported the average annual landings of " $R$. djiddensis" at Mumbai (mostly as bycatch in shrimp trawls) to be nearly $532.3 \mathrm{t}$ (1989-1993) which progressively declined to nearly $75 \mathrm{t}$ during 2012-2016 (CMFRI, 2013; 2014; 2015; 2016). The 
decline in landings may be attributed to legal frame work implemented in 2001, under Schedule 1 of the Wildlife (Protection) Act of 1972, by which India banned the exploitation and trade of 10 species of sharks, rays and guitarfishes. There have been very few studies on the biology of Rhynchobatus species from Indian waters. Setna and Sarangdhar (1949) studied breeding habits, while Raje (2006) analysed the length-weight relationship and feeding in Mumbai waters (northern Arabian Sea).

Elsewhere, $R$. laevis is an important component of coastal elasmobranch catches in tropical countries including Arabian Sea and the Bay of Bengal in Indian Ocean and off China and Japan in western pacific (Last et al., 2016b). This species has been targeted or exploited as incidental catch, primarily for fins and meat and is also a component of the bycatch in shrimp trawls in India and the 'white fins' are the main priced product. Few data are available on the population status; however, given its susceptibility to capture by multiple gear types, the known heavy fishing pressure from local and foreign vessels in parts of its range and its high value fins, it is highly likely that numbers significantly reduced and localised disappearance occurred (Tous et al., 1998; Dulvy et al., 2016; Moore, 2017; Jabado, 2018). Serious declines have occurred in populations of similar species for the same reasons, thus $R$. laevis is assessed as 'Critically Endangered' globally due to inferred population declines and continuing, unregulated high levels of exploitation (Kyne and Jabado, 2019). In fact, nearly all of the batoid species studied in other parts of the north-western Indian Ocean were either classed in the IUCN Red List as vulnerable, endangered or data deficient (Moore et al., 2012). Information on population size, fishery trends or biological data of $R$. laevis is limited (Setna and Sarangdhar, 1949; Raje et al., 2007) for making any assessment or management recommendations in Indian waters or northern Indian Ocean.

Guitarfishes form one of the most vulnerable groups in elasmobranchs (Dulvy et al., 2014; Moore, 2017; Jabado, 2018); their vulnerability compounded by the lack of detailed information on their reproduction, diet or stock status in the Indian Ocean. For this reason, the objective of this work was to focus on the reproduction, maturity and diet of $R$. laevis fished off north-west India, to update the information on life history of the species from the northern Indian Ocean.

\section{Materials and methods}

Specimens of $R$. laevis $(\mathrm{n}=328)$ were collected from landings of commercial shrimp trawlers, gillnetters, bag netters operating in the northern Arabian Sea, during 2012-2016. R. laevis was landed as bycatch in these fishing vessels which operated at $2-50 \mathrm{~m}$ depths. Specimens were collected from New Ferry Wharf (18 ${ }^{\circ} 57^{\prime} 28.85^{\prime \prime}$ $\mathrm{N}$; 72 ${ }^{\circ}$ 51' 02.73" E), Sassoon Dock (18 ${ }^{\circ} 4^{\prime}$ 42.43" N; 72॰ 49' 33.16" E), Satpati (19॰ 43'30.75", $\left.\mathrm{N} ; 72^{\circ} 42^{\prime} 08.30^{\prime \prime} \mathrm{E}\right)$ and Alibaug $\left(18^{\circ} 38^{\prime} 4.25^{\prime \prime} \mathrm{N} ; 72^{\circ}\right.$ $52 ' 38.95$ ” E) fisheries harbours in Maharashtra (Fig. 1).

For each species, the total length (TL) in mm and total body weight (TW) in $g$ were recorded along with the sex of the animal. For easier comparison with other studies, TL has been reported in $\mathrm{cm}$ for this study. Based on the

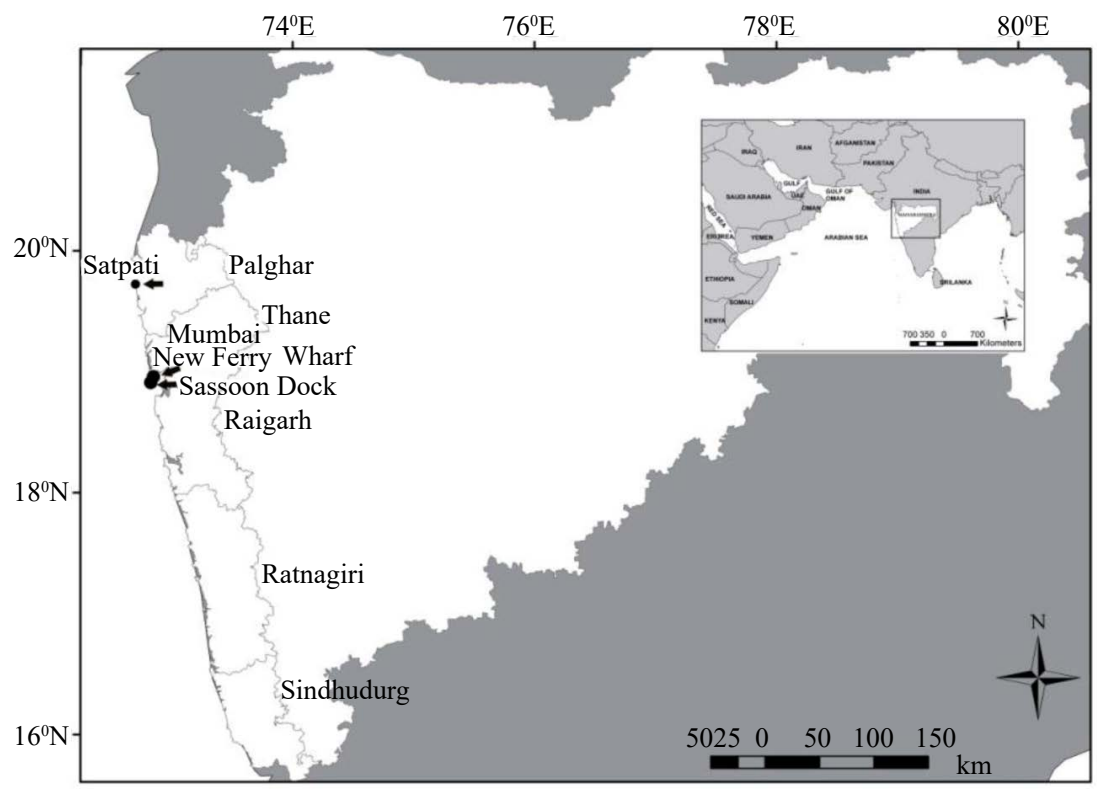

Fig. 1. Map showing the sites where samples of $R$. laevis were landed 
state of their umbilical scar (Purushottama et al., 2020) as well as TL, the animals were classified as neonates or juveniles.

Normality of the size-frequency distributions for each sex was tested using Shapiro-Wilk test (Shapiro and Wilk, 1965). Sex-based differences in size were tested using a two-tailed Student's t-test. Differences in male and female size-frequency distributions were tested using $\chi 2$ test (Cochran, 1952). Size-frequency distributions were calculated on size class intervals of $20 \mathrm{~cm}$. Sex ratio was tested using a two-sided exact ratio test (Biradar, 2002). Seasonal sex ratios were estimated for pre-monsoon (February-May), monsoon (June-September) and postmonsoon (October-January) seasons. The correlation between maternal TL and both number of embryos and mean embryo TL was also studied.

Sex of the animal was identified based on external morphological characters. Maturity of the animals was decided based on the scale proposed by Stehmann (2002) which used ovarian and uterine condition in females and extent of clasper calcification in males. Females were classified as immature if they had undeveloped ovaries and thin uteri, or mature if both ovaries and uteri were well developed. Males were classified as immature if they had uncalcified or partially calcified claspers and mature if they had fully calcified claspers. The relationship between inner clasper length (ICL) and TL was studied in males.

The $\mathrm{L}_{\mathrm{m}}$ for females and males was derived from a logistic regression as follows: $p \mathrm{~L}=\left\{1+\mathrm{e}\left[^{-\ln (19)\left(\mathrm{TL}^{-}\right.}\right.\right.$ $\left.\left.{ }^{\mathrm{TL}}{ }_{50}\right)\left({ }^{\mathrm{TL}}{ }_{95}-{ }^{\mathrm{TL}}{ }_{50}\right)^{]^{-1}}\right\}^{-1}$, where, $p \mathrm{~L}$ is the proportion of mature specimens; $\mathrm{TL}_{50}$ and $\mathrm{TL}_{95}$ are constants and ' $\mathrm{n}$ ' is the natural logarithm. Maximum likelihood estimates of the parameters were obtained using the routine SOLVER in Microsoft ${ }^{\mathrm{TM}}$ Excel and by calculating the likelihood of immature and mature individuals as $1-\mathrm{pL}$ and $\mathrm{pL}$, respectively. The reported estimates of the parameters were determined as the median values derived from 200 sets of randomly re-sampled data, with the same sample size, drawn from the data on the observed maturity status at TL for female and male guitar fishes. The c. 95\% confidence intervals (C.I.) were estimated as 2.5 and 97.5 percentiles of the 200 estimates resulting from these re-sampled data (Wood, 2004; White, 2007; Purushottama et al., 2017).

The sex-wise length-weight relationship (LWR) was estimated using the standard equation given by Le Cren (1951): $\mathrm{TW}=\mathrm{a}{ }^{*} \mathrm{TL}^{\mathrm{b}}$ after logarithmic transformation. The confidence intervals were estimated using the equations given by Montgomery et al. (2012). The male and female length-weight relationship was tested for significant difference using the extra sum of squares method (Montgomery et al., 2012).
Diet contents in the stomach of the animals were separated in the laboratory and identified up to the species level wherever possible. The weight of individual prey items was recorded along with their total counts in each stomach. From this, the percent index of relative importance $(\% \mathrm{IRI})$ was estimated as $\% \mathrm{IRI}=(\% N+\% W)^{*}$ $\% O$ (Pinkas et al., 1971), where $\% \mathrm{~N}$ is the percentage number of each prey item; $\% \mathrm{~W}$ the percentage by weight and $\% \mathrm{O}$ the percentage by occurrence of each prey item. IRI was expressed as \%IRI to allow for a comparison of the values between the prey groups (Cortes, 1997).

\section{Results}

A total of 328 individuals of $R$. laevis were examined in the field and laboratory, specimen lengths ranged from 45 to $290 \mathrm{~cm}$ TL $(165.4 \pm 4.9 \mathrm{~cm})$ and weight ranged from 300 to $94000 \mathrm{~g}(25100 \pm 1500 \mathrm{~g})$ for females and for males length ranged from 44 to $225 \mathrm{~cm}$ TL $(116.0 \pm 4.1 \mathrm{~cm})$ and weight ranged from 400 to $38000 \mathrm{~g}$ $(9700 \pm 700 \mathrm{~g})$.

Specimens were distributed into 14 size classes of $20 \mathrm{~cm}$ intervals each as depicted in Fig. 2. There was significant difference between female and male sizefrequency distributions $\left(\chi^{2}\right.$ test; $\left.\mathrm{p}<0.001\right)$, with more females between 205 and $245 \mathrm{~cm}$ TL and 65-165 cm TL for males captured.

Monthly length frequency distribution (pooled years) showed clear trends (Fig. 3) for females and males possibly due to changes in fishing patterns and area being observed in Maharashtra waters, wherein different habitats including shallow and inner continental shelf with muddy and sandy bottoms are fished in different seasons.

The overall sex ratio (F:M) was $1.73: 1$ in favour of females and was significantly different from 1:1 $(p<0.05)$. Sex ratio for the three seasons were: $2.4: 1$ (pre-monsoon), 0.8:1 (monsoon) and 1.8:1 (post-monsoon). Distribution of females and males of $R$. laevis was significantly different across sampling months $\left(\chi^{2}\right.$, d. f. $=9$, $\mathrm{p}<0.001)$.

Weight of $R$. laevis ranged from 300 to $94000 \mathrm{~g}$ in females and from 400 to $38000 \mathrm{~g}$ in males. The LWRs were estimated from 178 females (45-275 cm TL) and 104 males (44.0-225 cm TL) and the slopes were significantly different $(\mathrm{p}<0.001)$.

$$
\begin{aligned}
& \text { Females: } \mathrm{TW}=0.009412 \times \mathrm{TL}^{2.830218}\left(\mathrm{r}^{2}=0.979,95 \%\right. \text { C.I. of } \\
& b=3.260093-3.603260, n=178) \\
& \text { Males: TW }=0.004032 \times \mathrm{TL}^{3.031303}\left(\mathrm{r}^{2}=0.974,95 \%\right. \text { C.I. of } \\
& b=3.155264-3.487397, n=104)
\end{aligned}
$$

Mean monthly size was significantly different for females and males $\left(\chi^{2}\right.$, d. f. $\left.=9, p<0.001\right)$. In this study, 


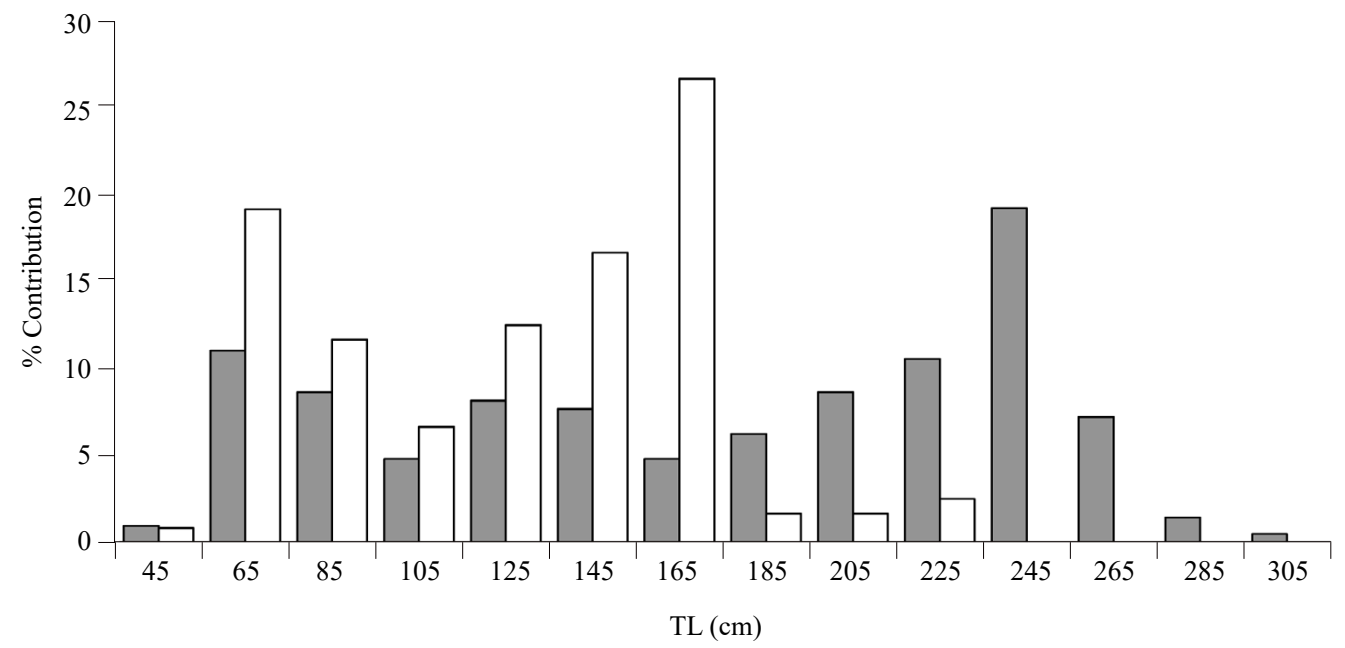

Fig. 2. Size frequency of $R$. laevis [Females $(\square), n=208$; Males $(\square), n=120]$

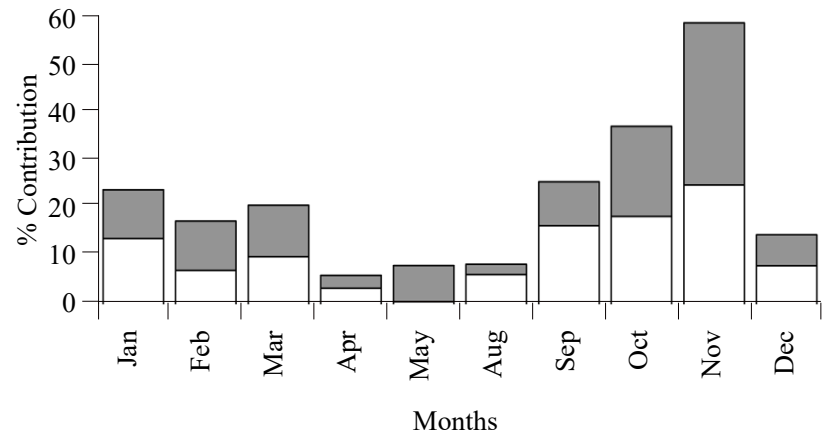

Fig. 3. Monthly percent contribution of females $(\square, n=208)$ and males ( $\square, n=120$ ) of $R$. laevis (January 2012 to December 2016)

21 pregnant females in the size range $180-275 \mathrm{~cm}$ TL $(236.9 \pm 28.7 \mathrm{~cm})$ were recorded. Late term embryos in advanced/fully developed stage were observed during September-December and January. Developing oocytes (60-75 $\mathrm{mm}$ dia) were observed in the functional ovary of females ( $>210 \mathrm{~cm} \mathrm{TL})$ and the smallest female containing maturing oocytes was of $180 \mathrm{~cm}$ TL. Mostly pregnant females contained 4-9 embryos per uterus, however, maximum embryos observed was 10 in a specimen measuring $180 \mathrm{~cm}$ TL and weighing $20.5 \mathrm{~kg}$.

Embryos ranged in size from $18-50 \mathrm{~cm}$ TL $(31.8 \pm 8.3 \mathrm{~cm})$, the length at birth in this species is at $c a .44$ to $50 \mathrm{~cm}$ TL based on length of the largest embryo (50 cm TL), length of smallest free swimming individual (44 cm TL) the length of the largest free swimming individual $(58 \mathrm{~cm}$ TL) that still had an open umbilical scar. Number of neonates and juveniles $(<100 \mathrm{~cm} \mathrm{TL})$ were 93 forming $28.4 \%$ of total observation and were observed during August-December and January-May.
Ninety-six mature females were observed among the 328 specimens of $R$. laevis examined. $\mathrm{L}_{\mathrm{m}}$ of females was estimated at $190(95 \%$ C.I. 185-195) cm TL (Fig. 4a). The smallest mature female recorded was $180 \mathrm{~cm}$ TL, while the largest immature female was of $245 \mathrm{~cm}$ TL. Since the reproductive cycle of this species did not follow a seasonal pattern, the timing of conception and parturition and the duration of gestation could not be determined. However, in the present study, gravid females were observed in pre-monsoon and monsoon seasons only. Thus, it can be assumed that pre-monsoon (February-May) and monsoon (June-September) are the peak parturition period.

Among the $R$. laevis specimens examined during the study, 50 mature males were observed. The smallest mature male recorded was of $124 \mathrm{~cm} \mathrm{TL}$, while the largest immature male was $195 \mathrm{~cm}$ TL. Males matured in different size range (125-145 $\mathrm{cm} \mathrm{TL)}$ and 50\% maturity occurred at 140 (95\% C.I. 135-145) cm TL (Fig. 4b). In the case of males, all maturity stages of $R$. laevis were presented, maturing size (sub-adult male) class $(9.2 \%)$ were $<129 \mathrm{~cm}$ TL. The vast majority of males $>140 \mathrm{~cm}$ TL possessed fully calcified claspers, while most between 100-119 cm TL possessed partially calcified claspers. The ICL of smallest male was $4 \mathrm{~cm}$ TL (specimen of $54 \mathrm{~cm} \mathrm{TL}$ ) while that of largest specimen was $40 \mathrm{~cm}$ TL (specimen of 225 $\mathrm{cm}$ TL) and there is noticeable increase in the ICL with TL (Fig. 5).

The stomach contents of specimens (44.0-290 $\mathrm{cm}$ TL) of $R$. laevis were studied and of these, $45.7 \%$ were empty. Only $30.5 \% \quad(n=100)$ contained prey items which could be identified. The identifiable prey items were found between 80 and $270 \mathrm{~cm}$ TL. The \%IRI revealed that $R$. laevis fed primarily 


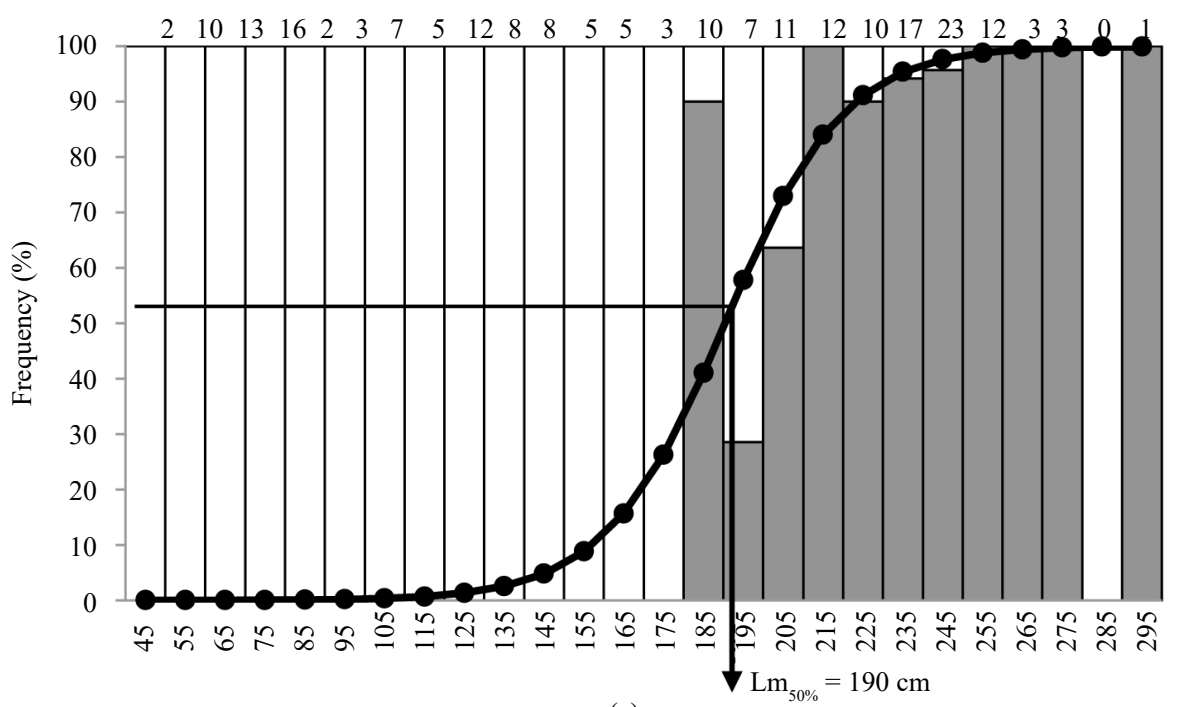

(a)

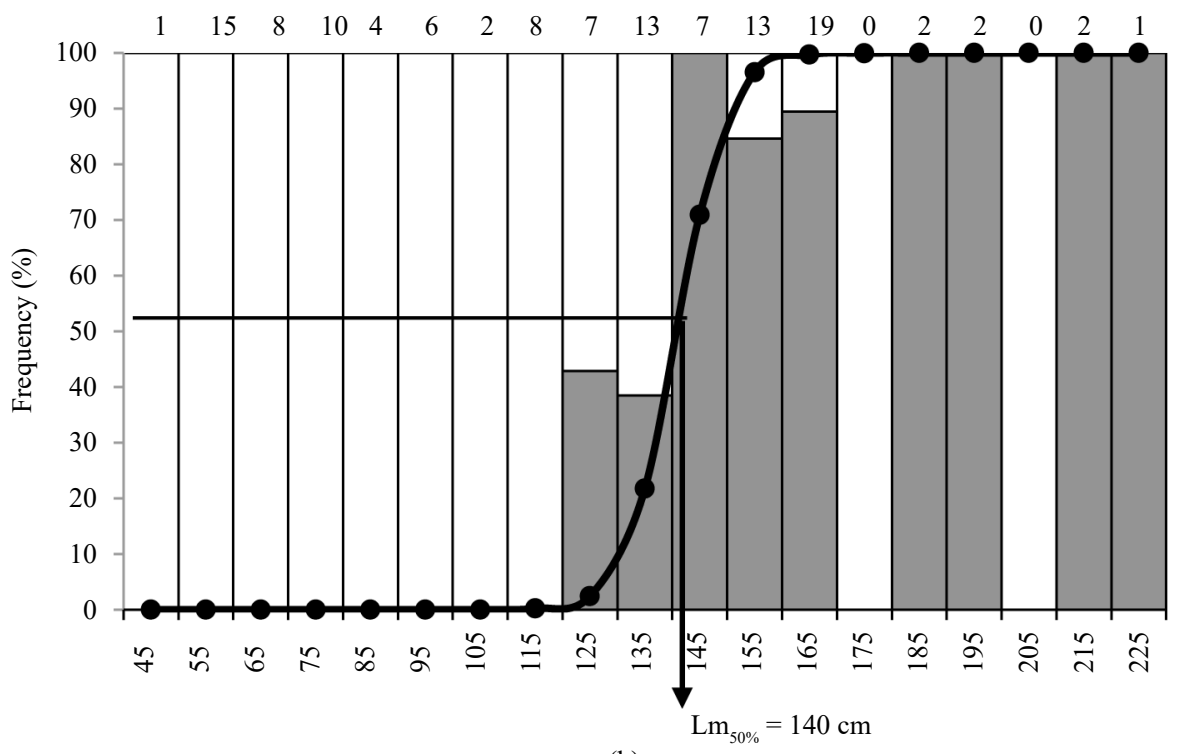

(b)

Fig.4. Percentage frequency of occurrence of immature $(\square)$ and mature ( $\square$ ) R. laevis in sequential total length (TL) classes for (a) females and (b) males. Numbers above each bar represent the sample size in each sequential TL class. Arrows indicate $\mathrm{L}_{\mathrm{m}}$

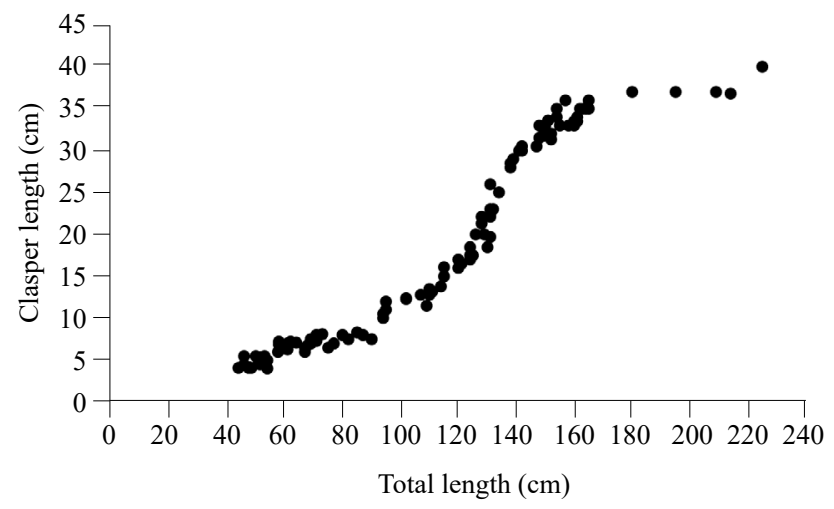

Fig. 5. Inner clasper length $v$ s. total length of males of $R$. laevis on teleosts $(83.4 \%)$, crustaceans $(15.1 \%)$ and cephalopods $(0.6 \%)$. Major prey items included Harpadon nehereus (\%IRI=72.5), Parapenaeopsis stylifera $(\% \mathrm{IRI}=13.2)$, Coilia spp. $(\% \mathrm{IRI}=4.6)$, Cynoglossus spp. (\%IRI = 3.9) and Stolephorus spp. $(\%$ IRI $=2.0)($ Table 1$)$.

\section{Discussion}

$R$. djiddensis species complex is rarely observed and reported from fishery catches in the present day, other than from northern Arabian Sea, where it was once considered to be common and contributed $>500 \mathrm{t} \mathrm{yr}^{-1}$ in fishery landings along north-west coast of India 
Table 1. Diet composition of R. laevis in north-eastern Arabian Sea

\begin{tabular}{|c|c|c|c|c|}
\hline Prey item & $\% N$ & $\% M$ & $\% O$ & $\%$ IRI \\
\hline \multicolumn{5}{|l|}{ Teleostei } \\
\hline $\begin{array}{l}\text { Engraulidae } \\
\quad \text { Stolephorus spp. }\end{array}$ & 15.9 & 15.6 & 13.1 & 2.0 \\
\hline Coilia spp. & 1.8 & 202 & 4.8 & 4.6 \\
\hline $\begin{array}{l}\text { Cynoglossidae } \\
\text { Cynoglossus spp. }\end{array}$ & 27.7 & 8.2 & 22.9 & 3.9 \\
\hline $\begin{array}{l}\text { Synodontidae } \\
\quad \text { Harpadon nehereus }\end{array}$ & 2.0 & 1555 & 9.8 & 72.5 \\
\hline $\begin{array}{l}\text { Other } \\
\text { Unidentified fishes }\end{array}$ & 7.0 & 8.1 & 5.7 & 0.4 \\
\hline \multicolumn{5}{|l|}{ Crustacea } \\
\hline $\begin{array}{l}\text { Sergestidae } \\
\text { Acetes } \text { spp. }\end{array}$ & 4.1 & 46.6 & 2.0 & 0.5 \\
\hline $\begin{array}{l}\text { Solenoceridae } \\
\quad \text { Solenocera spp. }\end{array}$ & 2.8 & 2.7 & 2.8 & 0.1 \\
\hline $\begin{array}{l}\text { Penaeidae } \\
\quad \text { Parapenaeopsis stylifera }\end{array}$ & 2.3 & 264 & 10.4 & 13.2 \\
\hline $\begin{array}{l}\text { Palaemonidae } \\
\quad \text { Nematopalemon tenuipes }\end{array}$ & 2.2 & 8.8 & 1.2 & 0.1 \\
\hline $\begin{array}{l}\text { Squillidae } \\
\quad \text { Oratosquilla spp. }\end{array}$ & 6.2 & 4.1 & 6.1 & 0.3 \\
\hline $\begin{array}{l}\text { Other } \\
\text { Unidentified shrimp }\end{array}$ & 10.2 & 6.0 & 11.5 & 0.9 \\
\hline $\begin{array}{l}\text { Other } \\
\text { Unidentified crab }\end{array}$ & 8.6 & 12.9 & 8.3 & 0.9 \\
\hline \multicolumn{5}{|l|}{ Mollusca } \\
\hline \multicolumn{5}{|l|}{ Cephalopoda } \\
\hline $\begin{array}{l}\text { Loliginidae } \\
\text { Loligo spp. }\end{array}$ & 9.3 & 5.3 & 9.2 & 0.6 \\
\hline
\end{tabular}

(Maharashtra and Gujarat) (Raje et al., 2007). Reports on the occurrence of $R$. laevis in the fishery are limited and may be unreported from many regions. Moreover, information on population sizes, fishery trends and biological data of $R$. laevis is limited (Setna and Sarangdhar, 1949; Raje et al., 2007) for conclusive stock assessment or management recommendations. The size range of $R$. laevis observed in this study $(44-290 \mathrm{~cm}$ TL) differed slightly from sizes of Rhynchobatus species complex reported from other regions. Wallace (1967) and Darracott (1977) examined 68 specimens of both sexes, from embryo to adults $(55.1-252.2 \mathrm{~cm} \mathrm{TL})$ and $131 \mathrm{fish}$ (up to $235 \mathrm{~cm} \mathrm{TL}$ ), respectively, off east coast of South Africa; Moore et al. (2012) in Kuwait and Qatar waters (73.0-149 cm TL for females and 81.0-177 cm TL for males, $n=19)$ and Jabado (2018) in UAE Gulf waters and Oman (78.9-283.9 cm TL for females, $n=108$ and 59.1-218.1 cm TL for males, $n=138$ ). However, Setna and Sarangdhar (1949) observed 13 individuals in length range between 213.4 to $297.2 \mathrm{~cm}$ TL, while Raje (2006) studied 606 specimens $(42.2-170 \mathrm{~cm}$ TL for females and
41.7-191 cm TL for males) and Gladston et al. (2018) observed 102 specimens (39.5-271 TL for females and 41.4-161 cm TL for males) in Mumbai waters. Furthermore, Weigmann (2016) recorded maximum length of $R$. laevis as $270 \mathrm{~cm}$ TL to date but our study recorded $290 \mathrm{~cm}$ TL as the new maximum length for this species. The differences in sizes seen could be due to differences in fishing gear selectivity, sample size and growth differences based on habitat (Motta et al., 2005). Differences in female and male size-frequencies might be a result of sexual segregation seen in elasmobranchs usually associated with reproduction, sex specific migration, competition or season (Ford, 1921; Steven, 1933; Springer, 1967; Klimley, 1987; Stevens and Mcloughlin, 1991; Motta et al., 2005; Mucientes et al., 2009; Wearmouth and Sims, 2010; Purushottama et al., 2017).

The sex ratio in favour of females (1.73:1), indicated potential sexual segregation in this species in the north-eastern Arabian Sea. This observation was further supported by differences in monthly sex ratios also. Seasonal and size-based sex ratios indicated the 
possibility of sexual aggregation in sub-adults and adults of $R$. laevis. This further indicated that females appeared to be more vulnerable to fishing than males in the study region. Nevertheless, observations made on $R$. djiddensis by Raje (2006) indicated that females and males appear to be equally distributed in the fishery during 1989-2003. Again Raje et al. (2012) made a similar observation with a female to male ratio $1.2: 1$ based on 606 specimens for 1999-2005 period from Mumbai waters. Our results are in agreement with Stobutzki et al. (2002), who also recorded from the bycatch, $R$. djiddensis in the northern Australian shrimp trawl fishery which comprised significantly more females than males. White and Dharmadi (2007) observed more females than males in the samples of $R$. australiae, Dasyatis cf. kuhlii, Gymnura poecilura, Dasyatis zugei, Himantura jenkinsii and Pteroplatytrygon violacea in a study covering 54 batoid species. Detailed information on sex ratios in regional fishery/populations of $R$. laevis throughout its known range would be required to determine any real trends in sexual segregation.

In this study, the length-weight relationship (TL vs. TW) of $R$. laevis was significantly different between the sexes. However, Darracott (1977) reported the length-weight relationship (combined sexes) as log $\mathrm{W}=-4.62+2.77 \log \mathrm{L}\left(\mathrm{r}^{2}=0.9 ; n=131\right)$ for $R$. djiddensis. Co-efficients ' $a$ ' and ' $b$ ' of the length-weight relationship were estimated as $-4.48,2.7\left(\mathrm{r}^{2}=0.85, n=41\right)$ for females and $-4.80,2.84\left(\mathrm{r}^{2}=0.88, n=37\right)$ for males, respectively, which indicated that growth in this fish is following allometry $(b<3)$ and there is no significant difference between females and males. Raje (2006) reported the length-weight relationship (pooled sexes) as log $\mathrm{W}=-12.1451+2.9794 \log \mathrm{L}(\mathrm{r}=0.97, n=418)$ in Mumbai waters and found that no significant difference in the regression coefficients between sexes. Gladston et al. (2018) recorded the length-weight relationship (combined sexes) as $\log \mathrm{W}=0.0034+3.0557 \log \mathrm{L}\left(\mathrm{r}^{2}=0.981, n=102\right)$. Co-efficients ' $a$ ', ' $b$ ' of the length-weight relationship were estimated as $0.0039,3.0238\left(\mathrm{r}^{2}=0.987, n=60\right)$ for females and $0.0021,3.1718\left(\mathrm{r}^{2}=0.959, n=42\right)$ for males, respectively in north-eastern Arabian Sea for $R$. djiddensis. On the contrary, our results show that females of $R$. laevis following allometric growth $(b<3$; the fish grows faster in length than in weight) and males $(b>3$; the fish grows faster in weight than in length) in the same study area. Our results on the life history traits and diet are the first reported for $R$. laevis and unfortunately, owing to the lack of biological studies in its geographic distribution, no data exists for comparisons. The differences between female and male LWRs could be attributed to a number of reasons including differing sample sizes, unequal distribution of sizes of each sex in the samples and presence of non-pregnant females or spent fish with lower condition factor (Stevens and Wiley, 1986).

The $\mathrm{L}_{\mathrm{m}}$ of females determined in this study was $190(185-195) \mathrm{cm}$ TL for $R$. laevis. Information on the length at maturity for females of $R$. laevis is limited, but in the same genus, for $R$. djiddensis, Darracott (1977) observed minimum and maximum length of a pregnant female measuring $118 \mathrm{~cm}$ TL with 6 embryos and $235 \mathrm{~cm}$ TL off the east coast of South Africa, respectively. However, observations made by Raje and Joshi (2003) show that smallest pregnant female observed during 1989-2003 period was $210 \mathrm{~cm}$ TL and Raje (2006) in another account opined that length at maturity was also same; whereas Raje et al. (2012) recorded only lowest length of matured female $(182 \mathrm{~cm} \mathrm{TL})$ while studying the breeding behaviour of elasmobranchs in Mumbai waters. These reports, indicate large variations in estimates of $\mathrm{L}_{\mathrm{m}}$ of females of the species.

The smallest adult male observed for $R$. laevis in the present study was $124 \mathrm{~cm}$ TL, whereas the smallest adult male observed by Raje (2006) and Raje et al. (2012) was $132 \mathrm{~cm}$ TL for $R$. djiddensis. The $\mathrm{L}_{\mathrm{m}}$ of males estimated in the present investigation was $140(135-145) \mathrm{cm}$ TL. Last et al. (2016b) reported that $R$. laevis males mature at $130 \mathrm{~cm}$ TL. In the same genus, Wallace (1967) and Darracott (1977) reported that mature males of $R$. djiddensis range from 130 to $136 \mathrm{~cm} \mathrm{TL}$ in east coast of South Africa and Western Indian Ocean, respectively. Carpenter and Niem (1998) and Last and Stevens (2010) reported that $R$. australiae, males matured at $131 \mathrm{TL}$ and female at 130 $\mathrm{cm}$ TL, respectively. However, males mature at a smaller size than female.

In this study, examination of a small number of pregnant females $(n=21)$, indicated that the mean number of embryos was 7 (range 4-10) and size at birth ranged between 44 and $50 \mathrm{~cm}$ TL. Setna and Sarangdhar (1949) and Raje (2006) observed that the most common number of young ones produced at a time was 8 , four from either uterus, although the maximum recorded was 10 and length at birth was 44 to $50 \mathrm{~cm}$ TL, while the maximum number of embryos recorded was 12 (Raje, 2006) for $R$. djiddensis. Generally, wedgefishes have limited biological productivity with small litter size and the present results are in agreement to that reported for R. laevis in Mumbai waters. In contrast, Wallace (1967) analysed only one gravid female with 4 advanced stage embryos and a small juvenile with umbilical scar (67 cm TL) and suggested the length at birth was 55.1-67 cm TL off the east coast of South Africa for $R$. djiddensis.

Furthermore, since pregnant females were observed in all 3 seasons and contained a wide range of embryonic 
developmental stages, i.e., from fertilised eggs to late-term embryos, this species appears to have a reproductive cycle not dependent on season. However, Setna and Sarangdhar (1949) had stated that the greatest reproductive activity for $R$. djiddensis appeared to be during the monsoon months for gravid females and those in early or intermediate stages of pregnancy was in August, September and October. For $R$. djiddensis, Wallace (1967) also recorded sexually active adult females during the months of January-March in east coast of Southern Africa. Darracott (1977) during a survey on elasmobranchs observed that maximum number of pregnant $R$. djiddensis were in November in Western Indian Ocean. Raje et al. (2007) reported that the peak breeding season for the species was July-October in north-west coast of India. The differences in seasonality of reproductive activity could be due to changes in fishing grounds and wider spatial coverage of fishing vessels than earlier years.

Last et al. (2016b) gave basic information on diet of this species, as a feeder of bottom-dwelling crustaceans and fishes. In this study, $R$. laevis was found to feed primarily on fishes $(83.4 \%)$, crustaceans $(15.1 \%)$ and cephalopods $(0.6 \%)$. The major prey items included $H$. nehereus $(\% \mathrm{IRI}=72.5), \quad$ P. stylifera $(\% \mathrm{IRI}=13.2)$, Coilia $\mathrm{spp}$. (\%IRI=4.6), Cynoglossus spp. (\%IRI=3.9), Stolephorus spp. (\%IRI=2.0), Loligo spp. (\%IRI=0.6) and Acetes spp. $(\% \mathrm{IRI}=0.5)$. The typical coastal prey items found in the stomachs indicate that $R$. laevis inhabits between $2-50 \mathrm{~m}$ depth, undertaking vertical and horizontal migration for breeding, nursery and feeding. In same genera, Wallace (1967) observed remains of crabs, squid and small fish, while Darracott (1977) briefly mentioned the diet of $R$. djiddensis, which included crustaceans, squid and eel in east coast of South Africa. Raje (2006) suggested that $R$. djiddensis fed on fishes (H. nehereus, Coilia dussumieri, Tripauchen vagina, sciaenids and Bregmaceros macclellandi) and crustaceans (Panulirus polyphagus, Nematopalaemon tenuipes, squilla, Acetes spp., P. stylifera and other shrimps).

In conclusion, elasmobranchs, including shark-like batoids have low resilience to overexploitation by fisheries because of their atypical life history traits including late attainment of maturity, low fecundity and natural mortality, slow growth, long life spans and the close relationship between the number of young ones produced and the size of breeding biomass (Stevens et al., 2000; Varghese et al., 2016). The restricted coastal habitat, limited life history characteristics, susceptibility to capture in multiple gears and ever growing demand place coastal rhynchobatids amongst the most vulnerable chondrichthyan fishes (Dudley and Cavanagh, 2006). $R$. australiae is commonly caught in the bycatch of the trawl fisheries in northern Australia and is the most sought after elasmobranch in Indonesia for its fins (Chen, 1996; Stobutzki et al., 2002; White and McAuley, 2003). Since, $R$. laevis shares similarity in both habitat and habits with $R$. australiae, it is fished heavily by gillnet fisheries and is also vulnerable to trawl nets and hooks (Compagno and McAuley, 2016). In India mostly gillnet fisheries exploit R. laevis and population status elsewhere is unclear. As per the global status of shark-like batoids based on the IUCN Red List of Threatened Species criteria, R. australiae and $R$. palpebratus were categorised as 'Vulnerable' and 'Not Evaluated' respectively (Froese and Pauly, 2018).

Taxonomic status of Rhynchobatus is unclear in Indian Ocean with several colour-morphs and new reports in fishery landings and possible cryptic species of R. djiddensis being reported (Dudley and Cavanagh, 2006; Bineesh et al., 2014; Henderson et al., 2016). Detailed taxonomic studies on the group over a broad geographical range with genetic studies and large-scale sampling is needed to resolve the taxonomic issues of Rhynchobatus spp. in Indian Ocean.

The life history patterns of chondrichthyans of Indian waters are poorly understood (Akhilesh et al., 2013; Kizhakudan et al., 2015; Purushottama et al., 2018). Most of the batoids in Arabian Sea are under tremendous fishing pressure (Jabado et al., 2017; Jabado, 2018), especially along Indian coast and declining catches of some batoid species from the Arabian Sea have been reported recently, despite increased effort (Raje and Zacharia, 2009). There is a paucity of detailed, recent studies on the biology and fisheries of inshore (sub-) tropical Indo-West Pacific Ocean batoids outside Australia, with a few exceptions (Raje, 2000; 2003; Raje et al., 2007; White and Dharmadi, 2007; Raje and Zacharia, 2009; Moore et al., 2012; Purushottama et al., 2020). Understanding the life history and habitat characteristics are highly important in sustainable fishery management. This article provides new detailed biological information on $R$. laevis in Indian waters, including sex, size composition, maturity, size of embryos and feeding habits, which is essential for the development of management plans for this poorly known and vulnerable elasmobranch species in India.

\section{Acknowledgements}

Authors are thankful to the Director, ICAR-CMFRI, Kochi for the support and the facilities provided. Mr. Swapnil S. Tandel, Ms. Dhanashree Bagade, Mr. B. B. Chavan and Mr. B. N. Katkar, Mumbai Research Centre of ICAR-CMFRI, Mumbai are acknowledged for support in field and laboratory. This work has been supported by the Indian Council of Agricultural Research, 
Ministry of Agriculture and Farmers Welfare, Govt. of India through ICAR-CMFRI under the project code FISHCMFRISIL201200500005.

\section{References}

Akhilesh, K. V., White, W. T., Bineesh, K. K., Ganga U. and Pillai, N. G. K. 2013. Biological observations on the bristly catshark Bythaelurus hispidus from deep waters off the south-west coast of India. J. Fish. Biol., 82: 1582-1591. doi: $10.1111 /$ jfb. 12087 .

Bineesh, K. K., Akhilesh, K. V., Sajeela, K. A., Abdussamad, E. M., Gopalakrishnan, A., Basheer, V. S. and Jena, J. K. 2014. DNA barcoding confirms the occurrence rare elasmobranchs in the Arabian Sea of Indian EEZ. Middle East J. Sci. Res., 19 (9): 1266-127. DOI: 10.5829/ idosi.mejsr.2014.19.9.13662.

Biradar, R. S. 2002. Course manual: Fisheries statistics, $2^{\text {nd }}$ edn. ICAR-Central Institute of Fisheries Education, Mumbai, India, $246 \mathrm{pp}$.

Carpenter, K. E. and Niem, V. H. 1998. FAO Species identification guide for fishery purposes: The living marine resources of the Western Central Pacific, vol. 2, Food and Agriculture Organisation of the United Nations, Rome, Italy.

Chen, H. K. 1996. Shark fisheries and the trade in sharks and shark products in South-east Asia. TRAFFIC South-east Asia Report, Petaling Jaya, Selangor, Malaysia.

CMFRI 2013. Annual report 2012-13. ICAR-Central Marine Fisheries Research Institute, Kochi, India, 200 pp.

CMFRI 2014. Annual report 2013-14. ICAR-Central Marine Fisheries Research Institute, Kochi, India, 274 pp.

CMFRI 2015. Annual report 2014-15. ICAR-Central Marine Fisheries Research Institute, Kochi, India, 353 pp.

CMFRI 2016. Annual report 2015-16. ICAR-Central Marine Fisheries Research Institute, Kochi, India, 294 pp.

Compagno, L. J. V. and McAuley, R. B. 2016. Rhynchobatus laevis. The IUCN Red List of Threatened Species 2016: e.T41854A68643153. http://dx.doi.org/10.2305/IUCNUK. 2016-1.RLTS.T41854A68643153.en. (Accessed 17 March 2018).

Cortes, E. 1997. A critical review of methods of studying fish feeding based on analysis of stomach contents: Application to elasmobranch fishes. Can. J. Fish. Aquat. Sci., 54: 726 -738. DOI: $10.1139 /$ cjfas-54-3-726.

Daracott, A. 1977. Availability, morphometries, feeding and breeding activity of multi-species, demersal fish stock of the western Indian Ocean. J. Fish Biol., 10(1): 1-16. https:// doi.org/10.1111/j.1095-8649.1977.tb04036.x.

Dudley, S. F. J. and Cavanagh, R. D. 2006. Rhynchobatus djiddensis. The IUCN Red List of Threatened Species 2006: e.T39394A10197912. http://dx.doi.org/10.2305/IUCN. UK.2006.RLTS.T39394A10197912.en. (Accessed 10 August 2017)
Dulvy, N. K., Fowler, S. L., Musick, J. A., Cavanagh, R. D., Kyne, P. M., Harrison, L. R., Carlson, J. K., Davidson, L. N. K., Fordham, S. V., Francis, M. P., Pollock, C. M., Simpfendorfer, C. A., Burgess, G. H., Carpenter, K. E., Compagno, L. J. V., Ebert, D.A., Gibson, C., Heupel, M. R., Livingstone, S. R., Sansciangco, J. C., Stevens, J. D., Valenti, S. and White, W. T. 2014. Extinction risk and conservation of the world's sharks and rays. eLife 3:e00590.

Dulvy, N. K., Davidson, L. N. K., Kyne, P. M., Simpfendorfer, C. A., Harrison, L. R., Carlson, J. K. and Fordham, S. V. 2016. Ghosts of the coast: Global extinction risk and conservation of sawfishes. Aquat. Conserv. Mar. Freshw. Ecosys., 26(1): 134-153. https://doi.org/10.1002/ aqc. 2525 .

Ford, E. 1921. A contribution to our knowledge of the life-history of the dogfishes landed at Plymouth. J. Mar. Biol. Ass. U. K., 12: 468-505.

Froese, R. and Pauly, D. 2018. FishBase. World Wide Web electronic publication. www.fishbase.org, (Accessed February 2018).

Gladston, Y., Akhilesh, K. V., Thakurdas, C., Ravi, O. P. K., Ajina, S. M. and Shenoy, L. 2018. Length-weight relationship of selected elasmobranch species from northeastern Arabian Sea, India. J. Appl. Ichthyol., 34(3): 753-757. https://doi. org/10.1111/jai.13680.

Henderson, A. C., Reeve, A. J., Jabado, R. W. and Naylor, G. J. P. 2016. Taxonomic assessment of sharks, rays and guitarfishes (Chondrichthyes: Elasmobranchii) from south-eastern Arabia, using the NADH dehydrogenase subunit 2 (NADH2) gene. Zool. J. Linn. Soc., 172(2): 399-442. https://doi.org/10.1111/zoi.12309.

Jabado, R. W. 2018. The fate of the most threatened order of elasmobranchs: Shark-like batoids (Rhinopristiformes) in the Arabian Sea and adjacent waters. Fish. Res., 204 448-457. https://doi.org/10.1016/j.fishres.2018.03.022.

Jabado, R. W., Kyne, P. M., Pollom, R. A., Ebert, D. A., Simpfendorfer, C. A., Ralph, G. M. and Dulvy, N. K. 2017. The conservation status of sharks, rays and chimaeras in the Arabian Sea and adjacent waters. UAE and IUCN Species Survival Commission Shark Specialist Group, Environment Agency - Abu Dhabi, Vancouver, Canada, $236 \mathrm{pp}$.

Klimley, A. P. 1987. The determinants of sexual segregation in the scalloped hammerhead shark Sphyrna lewini. Environ. Biol. Fish., 18(1): 27-40. DOI: 10.1007/BF00002325.

Kyne, P. M. and Jabado, R. W. 2019. Rhynchobatus laevis. The IUCN Red List of Threatened Species 2019: e.T41854A1244 22344. http://dx.doi.org/10.2305/IUCN UK.20192.RLTS.T41854A124422344.en. (Accessed 17 October 2019).

Last, P. R. and Stevens, J. D. 2009. Sharks and rays of Australia $2^{\text {nd }}$ edn. Harvard University Press, Massachusetts, USA. $664 \mathrm{pp}$. 
Last, P. R., Kyne, P. M. and Compagno, L. J. V. $2016 \mathrm{a}$. A new species of wedgefish Rhynchobatus cooki (Rhinopristiformes, Rhinidae) from the Indo-West Pacific. Zootaxa, 4139(2): 233-247. doi: 10.11646/zootaxa.4139.2.7.

Last, P. R., White, W. T., de Carvalho, M. R., Seret, B., Stehmann M. F. W. and Naylor, G. J. P. 2016b. Rays of the world. Comstock Publishing Associates. CSIRO Publishing, Clayton, Australia, i-ix +790 pp.

Le Cren, E. D. 1951. The length-weight relationship and seasonal cycle in gonad weight and condition in the perch (Perca fluviatilis). J. Anim. Ecol., 20: 201-219. https://doi. org/10.2307/1540.

Montgomery, D. C., Peck, E. A. and Vining, G. G. 2012. Introduction to linear regression analysis, $5^{\text {th }}$ edn. Wiley Publication, New Jersey, USA, 688 pp.

Moore, A. B. M., McCarthy, I. D., Carvalho, G. R. and Peirce, R. 2012. Species, sex, size and male maturity composition of previously unreported elasmobranch landings in Kuwait, Qatar and Abu Dhabi Emirate. J. Fish Biol., 80(5): 1619-1642. doi:10.1111/j.1095-8649. 2011. 03210.x.

Moore, A. B. M. 2017. Are guitarfishes the next sawfishes? Extinction risk and an urgent call for conservation action. Endangered Species Res., 34: 75-88. DOI: 10.3354/esr00830.

Motta, F. S., Gadig, O. B. F., Namora, R. C. and Braga, F. M. S. 2005. Size and sex compositions, length-weight relationship and occurrence of the Brazilian sharpnose shark, Rhizoprionodon lalandii, caught by artisanal fishery from south-eastern Brazil. Fish. Res., 74: 116-126.

Mucientes, G. R., Queiroz, N., Sousa L. L., Tarroso P., Sims, D. W. 2009. Sexual segregation of pelagic sharks and the potential threat from fisheries. Biol. Lett., 5: 156-159.

Pinkas, L., Oliphant, M. S. and Iverson, I. L. K. 1971. Food habits of albacore, bluefin tuna and bonito in California waters. Cal. Fish Game, 152: 1-105.

Purushottama, G. B., Ramasubramanian, V., Akhilesh, K. V., Raje, S. G., Thakurdas, Kizhakudan, S. J. and Zacharia, P. U. 2020. Biological observations on the Bengal guitarfish Rhinobatos annandalei Norman, 1926 from the Eastern Arabian Sea, India. Indian J. Fish., 67(2): 23-34. DOI: 10.21077/ijf.2019.67.2.94482-04.

Purushottama, G. B., Thakurdas, Ramasubramanian, V., Gyanaranjan, D., Akhilesh, K. V., Ramkumar, S., Kizhakudan, S. J., Singh, V. V. and Zacharia, P. U. 2017. Reproductive biology and diet of grey sharpnose shark Rhizoprionodon oligolinx Springer, 1964 (Chondrichthyes: Carcharhinidae) from the north-eastern Arabian Sea. Indian J. Fish., 64(4): 9-20. doi: 10.21077/ ijf.2017.64.4.63379-02.

Purushottama, G. B., Thakurdas, Tandel, S. S., Katkar, B. N., Chavan, B. B., Mhatre, V. D. Ramkumar, S. and Singh, V. V. 2018. Records of rare elasmobranchs and their biological observation from the north-eastern Arabian Sea, off Mumbai. Indian J. Geo-Mar. Sci., 47(8): 1566-1573.
Raje, S. G. 2000. Length-weight relationship of five species of rays from Mumbai, Maharashtra. Indian J. Fish., 47(2): 159-161.

Raje, S. G. 2003. Some aspects of biology of four species of rays off Mumbai water. Indian J. Fish., 50: 89-96.

Raje, S. G. 2006. Skate fishery and some biological aspects of five species of skates off Mumbai. Indian J. Fish., 53(4): 431-439.

Raje, S. G. and Joshi, K. K. 2003. Elasmobranchs. In: Status of exploited marine fishery resources of India. ICAR-Central Marine Fisheries Research Institute, Kochi, India, p. 92-101.

Raje, S. G., Sivakami, S., Mohan Raj, G., Manoj Kumar, P. P., Raju, A. A. and Joshi, K. K. 2007. An atlas on the elasmobranch fishery resources of India. Special Publication No. 95. ICAR-Central Marine Fisheries Research Institute, Kochi, India, 253 pp.

Raje, S. G., Thakurdas and Sujit, S. 2012. Relationship between body size and certain breeding behaviour in selected species of Elasmobranchs off Mumbai. J. Mar. Biol. Ass. India, 54(2): 85-89. doi: 10.6024/jmbai.2012.54.2.01691-14.

Raje, S. G. and Zacharia, P. U. 2009. Investigations on fishery and biology of nine species of rays in Mumbai waters. Indian J. Fish., 56: 95-101.

Setna, S. B. and Sarangdhar, P. N. 1949. The breeding habits of Bombay elasmobranchs. Rec. Indian Mus., 47: 107- 124.

Shapiro, S. S. and Wilk, M. B. 1965. An analysis of variance test for normality (complete samples), Biometrika, 52(3\&4): 591-611.

Springer, S. 1967. Social organisation of shark populations. In: Gilbert, P. W., Mathewson, R. F. and Rall, D. P. (Eds.), Sharks, skates and rays. John Hopkins University Press, Baltimore, USA, p. 149-174.

Stehmann, M. F. W. 2002. Proposal of a maturity stages scale for oviparous and viviparous cartilaginous fishes (Pisces, Chondrichthyes). Arch. Fish. Mar. Res., 50: 23 -48.

Steven, G. A. 1933. Rays and skates of Devon and Cornwall, III The proportions of the sexes in nature and in commercial landings and their significance to the fishery. J. Mar. Biol. Ass. UK., 18: 611-625.

Stevens, J. D., Bonfil, R., Dulvy N. K. and Walker, P. A. 2000 The effects of fishing on sharks, rays, and chimaeras (Chondrichthyans) and the implications for marine ecosystems. ICES J. Mar. Sci., 57: 476-494. doi:10.1006/ jmsc. 2000.0724 .

Stevens, J. D. and Mcloughlin, K. J. 1991. Distribution, size and sex composition, reproductive biology and diet of sharks from northern Australia. Aust. J. Mar. Freshw. Res., 42: 151-199. https://doi.org/10.1071/MF9910151.

Stevens, J. D. and Wiley, P. D. 1986. Biology of two commercially important Carcharhinidae sharks from northern Australia. Aust. J. Mar. Freshw. Res., 37: 671-688. 
Stobutzki, I. C., Miller, M. J., Heales, D. S. and Brewer, D. T. 2002. Sustainability of elasmobranchs caught as bycatch in a tropical prawn (shrimp) trawl fishery. Fish. Bull., 100: 800-821.

Talwar, P. K. and Kacker, R. K. 1984. Commercial sea fishes of India. Zoological Survey of India, Calcutta, India, 997 pp.

Tous, P., Ducrocq, M., Bucal, D. and Feron, E. 1998. Shark populations are possibly under serious threat in the Bijagos Archipelago (Biosphere Reserve), Guinea Bissau, West Africa. Shark News: Newsletter of the IUCN Shark Specialist Group, 10: 4.

Varghese, S. P., Gulati, D. K., Unnikrishnan, N. and Ayoob, A. E. 2016. Biological aspects of silky shark Carcharhinus falciformis in the eastern Arabian Sea. J. Mar. Biol. Ass. U. K., 96(7): 1437-1447. doi:10.1017/S0025315415001 575.

Wallace, J. H. 1967. The batoid fishes of the east coast of southern Africa, Part 1: Sawfishes and guitarfishes. South African Association for Marine Biological Research, Oceanographic Research Institute, Investigational Reports, 15: 1-32.

Wearmouth, V. J. and Sims, D. W. 2010. Sexual segregation in elasmobranchs. Biol. Mar. Mediterr., 17(1): 236-239.
Weigmann, S. 2016. Annotated checklist of the living sharks, batoids and chimaeras (Chondrichthyes) of the world, with a focus on biogeographical diversity. J. Fish Biol., 88(1): 1-201. http://dx.doi.org/10.1111/jfb.12874.

White, W. T. and McAuley, R. 2003. Rhynchobatus australiae. The IUCN Red List of Threatened Species 2003: e.T41853A10580429. SSG Australia and Oceania Regional Workshop, March 2003. http://dx.doi.org/10. 2305/IUCN. UK.2003.RLTS.T41853A10580429.en. (Accessed 17 March 2018).

White, W. T. and Dharmadi. 2007. Species and size composition and reproductive biology of rays (Chondrichthyes, Batoidea) caught in target and non-target fisheries in eastern Indonesia. J. Fish Biol., 70: 1809-1837. doi: 10.1111/j/1095-8649. 2007.01458.x

White, W. T. 2007. Catch composition and reproductive biology of whale sharks (Carcharhiniformes: Carcharhinidae) caught by fisheries in Indonesia. J. Fish Biol., 71(5): 1512-1540. doi: 10.1111/j/1095-8649.2007.01623.x.

Wood, M. 2004. Statistical inference using bootstrap confidence intervals. Significance 1: 180-182. https://doi. org/10.1111/j.17 40-9713.2004.00067.x. 